\title{
IMPLEMENTASI DESAIN PEMBELAJARAN BERMAIN PERAN DALAM MENINGKATKAN HASIL BELAJAR SEJARAH KEBUDAYAAN ISLAM DI MTS BADRUSSALAM SURABAYA
}

\author{
Nurul Kumalasari \\ Universitas Islam Negeri Sunan Ampel Surabaya, Indonesia \\ Email: nurulkumala03@gmail.com
}

\begin{abstract}
This study aims to describe the various strategies carried out in implementing the learning design of Role Play in improving the Learning Outcomes of Islamic Cultural History. This research is a descriptive study using a qualitative approach. This research was conducted at MTS Badrussalam Surabaya, with student subjects. Data collected through observation, interviews, and documentation. The data validity checking technique used is the triangulation technique. The results showed that the role play learning design is one of the learning designs that can be used in the learning process of Islamic Cultural History and can provide an overview of subject matter or thinking that is still abstract into a pleasant understanding, meaning that learning becomes more concrete. Some strategies that must be considered by educators in implementing fun and non-boring learning designs such as educators must be aware of the latest learning designs in teaching and learning, educators must have the ability to increase the success of student learning, educators are able to develop learning designs, manage learners and conduct an evaluation, and learners accept and can apply the role playing learning design.
\end{abstract}

Keywords: Role Play, Learning Outcomes, History of Islamic Culture

\begin{abstract}
Abstrak: Penelitian ini bertujuan untuk mendiskripsikan berbagai strategi yang dilakukan dalam mengimplemtasikan desain pembelajaran Bermain Peran dalam meningkatkan Hasil Belajar Sejarah Kebudayaan Islam. Penelitian ini merupakan penelitian deskriptif dengan menggunakan pendekatan kualitatif. Penelitian ini dilakukan di MTS Badrussalam Surabaya, dengan subjek siswa. Data dikumpulkan melalui observasi, wawancara, dan dokumentasi. Teknik pemeriksaan keabsahan data yang digunakan adalah teknik triangulasi. Hasil penelitian menunjukkan bahwa desain pembelajaran Bermain Peran merupakan salah satu desain pembelajran yang dapat digunakan dalam proses pembelajaran Sejarah Kebudayaan Islam dan dapat memberi gambaran terhadap materi pelajaran atau pemikiran yang masih abstrak menjadi sebuah pemahaman yang menyenangkan, artinya pembelajaran menjadi lebih konkrit. Beberapa strategi yang harus diperhatikan pendidik dalam mengimplementasikan desain pembelajaran yang menyenangkan serta tidak membosankan seperti pendidik harus menyadari tentang desain pembelajaran yang terbaru dalam belajar mengajar, pendidik harus memiliki kemampuan yang dapat menigkatkan keberhasilan belajar peserta didik, pendidik mampu mengembangakan desain pembelajaran, mengatur peserta didik dan mengadakan evaluasi, dan peserta didik menerima dan dapat menerapkan desain pembelajaran bermain peran.
\end{abstract}

Kata Kunci: Bermain Peran, Hasil belajar, Sejarah Kebudayaan Islam 


\section{Pendahuluan}

Pembelajaran merupakan proses terjadinya interaksi antara peserta didik dengan sumber belajar, namun kenyataannya proses pembelajaran yang berlangsung hanya berpusat pada guru. Idealnya belajar menjadi kebutuhan sesuai peserta didik dan guru hanya menjadi fasilitator untuk keberlangsungan belajar yang berkualitas. Gurulah yang mencipakannya guna membelajarkan anak didik. guru yang mengajar dan anak didik yang belajar. Perpaduan dari kedua unsure manusiawi ini lahirlah interaksi edukatif dengan memanfaatkan bahan sebagai mediumnya. Di sana semua komponen pengajaran diperankan secara optimal guna untuk mencapai tujuan pengajaran yang telah ditetapkan sebelum pengajaran dilaksanakan. ${ }^{1}$

Guru memiliki peran penting dalam mengemban kegiatan belajar mengajar, seperti mendidik, mengajar dan melatih. Mendidik berarti mengembangkan nilai hidup. Sedangkan mengajar lebih kepada memajukan ilmu pengetahuan dan teknologi. Dan terakhir melatih yaitu menumbuhkan keterampilan peserta didik. ${ }^{2}$ memiliki pengertian Guru menjadi satu dari beberapa faktor menentukan keberhasilan belajar peserta didik untuk menciptakan pengalaman berbeda dengan menggunakan media.

Media menjadi jembatan interaksi guru dengan peserta didik. Proses belajar mengajar sering dihadapkan dengan materi yang abstrak sehingga sulit di pahami oleh peserta didik, dengan adanya media diharapkan pembelajaran menjadi lebih konkrit, seperti menvisualkan pelajaran-pelajaran yang sulit diterima oleh peserta didik dengan gambar, tujuannya agar dapat mengkongkritkan keadaan abstrak di buku menjadi lebih nyata dan menarik. ICT (Information and Communication of Technology) sebagai media yang terlibat dalam pendidikan mempunyai kecenderungan menarik minat dan memberikan kemanfaat dalam proses pembelajaran. ${ }^{3}$ Oleh karena itu perlunya kesinambungan antara guru dengan peserta didik dalam mengaplikasikan media, tujuannya agar peserta tidak merasa bosan dan monoton belajar di kelas.

Sejaran Kebudayaan Islam (SKI) merupakan salah satu cabang mata pelajaran pendidikan agama islam yang diberikan sejak dari tingkat Madrasah Ibtidaiyah (MI) sampai Perguruan Tinggi (PT), khususnya Perguruan Tinggi Agama Islam (PTAI). Pada umumnya Sejarah Kebudayaan Islam dirasakan lebih sulit untuk dipahami dari pada ilmu- ilmu lainnya. Salah satu penyebabnya adalah karena sejarah mempelajari sesuatu yang sudah terjadi dan tidak dialami oleh peserta didik, dan tidak adanya kesesuaian antara kemampuan peserta didik dengan cara penyajian materi sehingga SKI dirasakan sebagai pelajaran yang sulit untuk diterima.

Sejarah Kebudayaan Islam di Madrasah Tsanawiyah merupakan salah satu bagian pelajaran PAI yang dipelajari dengan membahas perkembangan Islam, peranan, tokoh berprestasi pada masa lampau, dan peranan kebudayaan Islam atau pun pra Islam, dari sejarah kelahiran Nabi Muhammad Saw, peradaban dan kebudayaan dinasti umayah, peristiwa Fathu Makkah, hingga wafatnya Nabi. Secara subtansial Sejarah Kebudayaan Islam memberikan kontribusi dalam memberikan motivasi kepada siswa untuk mengenal, menghayati, memahami Islam dengan mengandung nilai-nilai kearifan guna melatih kecerdasan, membentuk sikap, watak dan kepribadian. Kesan pembelajaran sejarah yang sering kali membosankan, penggunaan metode pembelajaran model visual sangat guna

\footnotetext{
${ }^{1}$ Bermawy M, Hisyam Zaini, and Sekar A.A, Strategi Pembelajaran Aktif (Yogyakarta: Pustaka Insan Madani, 2008).

${ }^{2}$ Uzer Usman, Menjadi Guru Profesional (Bandung: Remaja Rosdakarya, 2002). 19.

${ }^{3}$ Rosdiana, "Penggunaan Media Pembelajaran Berbasis ICT Dan Pengaruhnya Terhadap Tingkat Kelulusan Ujian Nasional Siswa Pada Sekolah Menengah Di Kota Palopo (Studi Kasus Di 5 Sekolah Menengah Di Kota Palopo)," Al-Khawarizmi; Jurnal Pendidikan Matematika dan Ilmu Pengetahuan Alam 4, 1 (March 2016).
} 
menciptakan suasana kelas yang lebih aktif dan menyenangkan, selain itu diharapkan dapat meningkatan motivasi belajar siswa.

Tujuan pembelajaran dikatakan berhasil ditentukan oleh beberapa faktor, antara lain: pedidik ketika melakukan proses belajar mengajar, karena guru secara langsung mempengaruhi, membina dan meningkatkan kecerdasan serta keterampilan siswa. Untuk mengatasi permasalahan tersebbut, guna mencapai tujuan pendidikan secara maksimal, sehingga dapat disimpulkam guru berperan sangat penting dan pendidik diharapkan dapat menegmbangkan dan memiliki model pengajaran terbaru yang baik dan mampu memilih model pembelajaran yang tepat yang sesuai dengan kompetensi mata pelajaran yang akan disampaikan kepada peserta didik.

Untuk itu dibutuhkan suatu kegiatan yang dilakukan oleh guru dengan upaya membangkitkan keaktifan dan motivasi belajar siswa, misalnya dengan membimbing siswa untuk terlibat langsung dalam kegiatan yang melibatkan siswa serta guru yang berperan sebagai pembimbing untuk menemukan konsep SKI. Salah satu metode yang akan diterapkan untuk meningkatkan kualitas hasil belajar siswa dan siswi MTS Badrussalam yaitu Metode Role Playing. Metode role playing atau bermain peran merupakan cara pembelajaran yang membimbing peserta didik untuk melakukan kegiatan memainkan peranan tertentu seperti yang terdapat dalam kehidupan masyarakat. ${ }^{4}$ Dari latar belakang tersebut di atas, penulis tertarik untuk melihat dan meneliti Implementasi desain Pembelajaran Role Playing (Bermain Peran) dalam Meningkatkan Hasil Belajar Sejarah Kebudayaan Islam Materi Perkembangan Kebudayaan/Peradaban Islam pada Masa Dinasti Umayyah di MTS Badrussalam.

\section{Metode Penelitian}

Metode Penelitian yang digunakan adalah deskriptif dengan menggunakan pendekatan kualitatif. Penelitian ini bertujuan untuk mendeskripsikan implementasi desain pembelajaran bermain peran dalam meningkatkan hasil belajar siswa. Penelitian ini dilakukan di MTS Badrussalam Surabaya. Teknik pengumpulan data yang digunakan dalam penelitian ini adalah wawancara, observasi, dan dokumentasi. ${ }^{5}$ Wawancara me- rupakan percakapan dengan maksud tertentu. Percakapan itu dilakukan oleh dua pihak, yaitu pewawancara (interviewer) yang mengajukan pertanyaan dan yang diwawancarai yang memberikan jawaban atas pertanyaanitu. Wawancara digunakan untuk menjaring data atau informasi yang berkaitan dengan berbagai desain pembelajaran dalam meningkatkan hasil belajar siswa. Observasi dilakukan untuk melihat implementasi desain pembelajaran bermain peran dalam meningkatkan hasil belajar siswa di sekolah. Dokumentasi digunakan untuk memperoleh data tentang desain dan rencana pembelajaran yang dibuat oleh guru. Untuk memperoleh data yang dapat dipertanggung jawabkan secara ilmiah, dalam penelitian ini dilakukan pemeriksaan keabsahan data. Dalam penelitian ini teknik pemeriksaan keabsahan data yang digunakan adalah teknik triangulasi.

\footnotetext{
${ }^{4}$ Asis, Ika, Pembelajaran Efektif, (Bandung: PT Remaja Rosdakarya, , 2014)

${ }^{5}$ L.J. Moleong, Metode Penelitian Kualitatif (Bandung: Remaja Rosda Karya, 2007).
} 


\section{Kajian Teori}

\section{Media Pembelajaran Role Playing (Bermain Peran)}

Penggunaan role playing (bermain peran) sebagai penunjang pembelajaran merupakan bagian dari pengembangan bahan ajar. role playing (bermain peran) merupakan bagian dari media pembelajaran berbasis ICT, dalam pengertiannya media diartikan sebagai penyampai pesan dari suatu tempat ke tempat lain, atau sebagai perantara. ${ }^{6}$ Fleming memberikan pengertian bahwa media merupakan penyebab atau alat menyatukan dua belah pihak. Media menunjukan fungsi perannya sebagai mediator penghubung yang efektif dalam belajar bagi peserta didik dengan isi pelajarannya. Di samping itu media mencerminkan pengertian sebagai pihak penyelesai segala persoalan dan kemudahan yang terjadi pada sistem pembelajaran, mulai dari guru sampai kepada peralatan yang paling canggih dapat disebut media. Ringkasnya media adalah alat yang menyampaikan atau mengantarkan pesan-pesan pembelajaran. ${ }^{7}$

Menurut Gagne, media meruapakan segala komponen yang berada dalam lingkungan peserta didik dapat merangsang dalam aktivitas belajarnya. ${ }^{8}$ Sedangkan pembelajaran merupakan upaya pemberian stimulus, pengarahan, bimbingan, pengarahan, dan dorongan kepada peserta didik dalam terjadinya proses belajar. Menurut Gagne dan Briggs, pembelajaran adalah proses membelajarkan peserta didik yang diselenggarakan oleh guru dalam belajar, bagaimana memproses dan mengolah pengetahuan, serta keterampilan dan sikap. Dalam pengertian lain diartikan sebagai proses interaksi antara guru dan peserta didik, dengan tujuan penyaluran pengetahuan maupun sikap dan keterampilan. ${ }^{9}$ Jadi dapat disimpulkan media pembelajaran merupakan segala sesuatu yang digunakan dalam menyampaikan atau perantara sarana belajar, guna merangsang perhatian, minat, pikiran, dan perasaan peserta didik, hal ini menjadikan media sebagai komponen penghubung dari sistem pembelajaran.

Gerlach dan Ely mengemukakan terdapat tiga karakteristik penggunaan media pembalajaran dimana untuk mengantisipasi kurang efektifnya guru dalam mengajar, diantaranya a) fiksatif; media mampu merekam, melestarikan, dan merekonstruksi suatu peristiwa, b) manipulatif; kemampuan media untuk menstransformasi suatu objek, mengatasi masalah ruang dan waktu, c) distributif; menggambarkan kemampuan media mentransformasikan objek melalui ruang, dan mampu menyajikan pada jumlah peserta didik yang besar. ${ }^{10}$ Media menjadi sarana penting dalam penyalur komunikasi pembelajaran yang akan selalu terlibat dalam proses pembelajaran. Dalam proses pembelajaran media terdapat dua macam, "' yaitu media tradisional, seperti papan tulis, modul, lembar peraga, buku teks, LKS, media massa dll. Dan Media berbasis modern seperti computer, smartphone, internet, multimedia, dll. Pemanfaatan media teknologi modern dalam pembelajaran bahasa khususnya keterampilan berbicara siswa melalui model bermain peran sangat penting. Siswa dimotivasi untuk berbicara dengan cara memahami dan memainkan peran sesuai dengan tema yang dipilih. Dengan bermain peran, siswa dituntut berinteraksi dengan pemain yang lain yang memainkan peran lain. Bermain peran dalam pembelajaran berusaha untuk membantu

\footnotetext{
${ }^{6}$ M. Rudy Sumiharsono and Hisbiyatul Hasanah, Media Pembelajaran (Jember: Pustaka Abadi, 2018). 9.

${ }^{7}$ Husniyatus Salamah Zainiyati, Pengembangan Media Pembelajaran Berbasis ICT (Jakarta: Kencana, 2017). 62.

${ }^{8}$ Nunuk Suryani, "Pengembangan Media Pembelajaran Berbasis IT," Prosiding Workhsop Nasional (November 2015). 3.

${ }^{9}$ Sunhaji, "Konsep Manajemen Kelas Dan Implikasinya Dalam Pembelajaran," Jurnal Kependidikan 2, 2 (November 2014). 34.

${ }^{10}$ Nizwardi Jalinus and Ambiyar, Media Dan Sumber Pembelajaran (Jakarta: Kencana, 2016). 15.

${ }^{11}$ Suryani, "Pengembangan Media Pembelajaran Berbasis IT." 4.
} 
individu dalam hal ini siswa untuk memecahkan masalah melalui peragaan serta langkahlangkah identifikasi masalah, analisis, pemeranan, dan diskusi.

Bermain peran dikenal sebagai salah satu model penyajian pada hampir semua jenjang pendidikan. Model penyajian ini menjadi sangat digemari karena sejak kecil anak-anak sudah gemar bermain peran, sehingga dalam proses belajar mengajar bermain peran adalah sesuatu kegiatan yang menyenangkan. Metode bermain peran adalah berperan atau memainkan peranan dalam dramatisasi masalah sosial atau psikologis. Bermain peran merupakan bentuk permainan pendidikan yang digunakan untuk menjelaskan perasaan, sikap atau tingkah laku dan nilai dengan tujuan untuk menghayati perasaan, sudut pandang dan cara berfikir orang lain. ${ }^{12}$

Bermain peran merupakan desain pembelajaran yang menyenangkan bagi pesertta didik, karena mereka dapat mengeksplor kemampuan bahasa, kognitif, serta fisik motorik. Sehingga desain pembelajaran bermain peran menjadi salah satu pembelajaran yang mengajak peserta didik turut aktif dalam pembelajaran dengan memerankan materi yang akan diajarkan. Sehingga kemampuan kognitif, sosioemosional dan motoric peserta didik meningkat dengan baik dan dapat meningkatkan hasil belajar peserta didik dengan baik. Tujuan bermain peran adalah mengajak peserta didik mengeksplorasi kemampuan bahasa dan pemahaman materi menjadi lebih dalam, sehingga dapat dipraktekkan pada kehidupan sehari-hari, selain itu bermain peran menjadi alternatif desain pembelajaran yang menyenangkan dan dapat menghidupkan kelas.

\section{Hasil Belajar Sejarah Kebudayaan Islam}

Hasil belajar diartikan sebagai hasil maksimum yang telah dicapai oleh siswa setelah mengalami proses belajar mengajar dalam mempelajari materi pelajaran tertentu. Hasil belajar tidak mutlak berupa nilai saja, akan tetapi dapat berupa perubahan atau peningkatan sikap, kebiasaan, pengetahuan, keuletan, ketabahan, penalaran, kedisiplinan, ketrampilan dan yang menuju pada perubahan positif. Hasil belajar menunjukkan kemampuan siswa yang sebenarnya dan telah mengalami proses pengalihan ilmu pengetahuan dari seseorang yang dapat dikatakan dewasa. Jadi, dengan adanya hasil belajar, pendidik dapat mengetahui seberapa jauh siswa dapat menangkap, memahami, memiliki materi pelajaran tertentu. Atas dasar itu pendidik dapat menentukan strategi belajar-mengajar yang lebih baik.

Sejarah Kebudayaan Islam di Madrasah Tsanawiyah merupakan salah satu bagian pelajaran PAI yang dipelajari dengan membahas perkembangan Islam, peranan, tokoh berprestasi pada masa lampau, dan peranan kebudayaan Islam atau pun pra Islam, dari sejarah kelahiran Nabi Muhammad Saw. hijrah ke madinah, peristiwa Fathu Makkah, hingga wafatnya Nabi. Secara subtansial Sejarah Kebudayaan Islam memberikan kontribusi dalam memberikan motivasi kepada siswa untuk mengenal, menghayati, memahami Islam dengan mengandung nilai-nilai kearifan guna melatih kecerdasan, membentuk sikap, watak dan kepribadian.

Kesan pembelajaran sejarah yang sering kali membosankan, penggunaan metode pembelajaran model bermain peran (role playing) sangat guna menciptakan suasana kelas yang lebih aktif dan menyenangkan, selain itu diharapkan dapat meningkatan motivasi belajar siswa. Bermain peran (role playing) menjadi bagian penting dalam pembelajaran, khususnya di MTs Badrussalam Surabaya. Pengembangan bahan ajar dilakukan dengan konsep penelitian tindakan kelas, hal ini bertujuan untuk memperbaiki mutu praktik

\footnotetext{
${ }^{12}$ Depdiknas, Pedoman Khusus Pengembangan Silabus Berbasis Kompetensi SMP Mata Pelajaran PAI, (Jakarta: Direktorat Jendral Pendidikan Lanjutan Pertama, 2003).
} 
pembelajaran di kelas. ${ }^{13}$ Disamping itu, metode ini dapat meningkatkan hasil belajar peserta didik. Peserta didik merasa enjoy dan senang saat belajar, karena mereka dapat memerankan dan merasakan langsung pembelajaran Sejarah Kebudayaan Islam.

\section{Hasil Penelitian}

Berdasarkan hasil penelitian, dalam meniingkatkan hasil belajar Mata Pelajaran Sejarah Kebudayaan Islam, peneliti dan guru bekerjasama dalam menyusun desain pembelajaran yang menyenangkan dan membuat para peserta didik tidak merasa bosan. Strategi yang dilakukan MTS Badrussalam dalam mengimplementasikan desain pembelajaran dalam meningkatkan hasil belajar Sejarah Kebudayaan Islam.

Peneliti dan guru bekerjasama dalam memnyusun dan membuat Paket Program pembelajaran. Paket program pembelajaran yang bersifat self-contained dan self-instruction, yaitu desain pembelajaran mandiri dan kelompok. Modul pembelajaran digunakan untuk menunjang Desain Pembelajaran yang telah disiapkan oleh guru dan bekerjasama dengan peserta didik. Sehingga pembelajaran menjadi lebih hidup dan tidak membosankan, peserta didik dapat bereksplorasi serta dapat berfikir kreatif.

Desain Pembelajaran tersebut dipilih dalam pembelajaran Sejarah Kebudayaan Islam karena sudah dipersiapkan oleh guru dan peserta didik, dan tidak membutuhkan banyak biaya, serta mudah dioperasikan oleh semua pendidik dan aman untuk digunakan. Selain itu, Desain Pembelajaran tersebut juga sesuai dengan materi pembelajaran dan kebutuhan peserta didik. Menurut beberapa narasumber yang menjadi guru Sejarah Kebudayaan Islam di MTs Badrusaalam. ${ }^{14}$ Pemilihan dan penggunaan Desain Pembelajaran berupa modul pembelajaran dengan metode role playing (bermain peran) adalah langkah awal yang dilakukan guru, agar pembeelajaran Sejarah Kebudayaan Islam tidak monoton dan menggunakan metode ceramah, sehingga kelas menjadi lebih hidup ketika pembelajaran. Karena semua orang memandang bahwa pelajaran Sejarah Kebudayaan Islam hanya berisi kumpulan kisah para pendahulu, dan pembelajaran hanya dapat disampaikan dengan metode ceramah dan konvensional. Pembelajaran di kelas merupakan hal yang sangat penting dalam suatu proses belajar mengajar.

Menurut UU No. 20 Tahun 2003 tentang Sistem Pendidikan Nasional bahwa Pembelajaran adalah proses interaksi antara peserta didik dengan pendidik dan sumber belajar pada suatu lingkungan belajar. Hal tersebut tercantum pula dalam PP No. 19 Tahun 2005 tentang Standar Nasional Pendidikan pasal 19 Ayat (1) bahwa Proses pembelajaran pada satuan pendidikan diselenggarakan secara interaktif, inspiratif, menyenangkan, menantang, memotivasi peserta didik untukberpartisipasi aktif, serta memberikan ruang yang cukup bagi prakarsa,kreativitas, dan kemandirian sesuai dengan bakat, minat, dan perkembangan fisik serta psikologis peserta didik.

Berdasarkan standar proses yang telah ditetapkan dalam PP No. 19 tahun 2005 tersebut pada dasarnya menjadi suatu pedoman dan panduan bagi para guru diberbagai jenjang pendidikan untuk menerapkan pembelajaran PAIKEM (Pembelajaran Aktif Inovatif, Kreatif, Efektif, dan menyenangkan) oleh sebab itu sudah sepatutnya jika menjadi seorang guru dituntut untuk mampu memainkan perannya yang tidak hanya sebagai komunikator, melainkan juga meliputi peran sebagai mediator, fasilitator dan membantu siswa untuk mecapai tujuan pembelajaran. ${ }^{15}$ Dewasa ini jika melihat dan mengamati kinerja guru-guru di Indonesia saat proses pembelajaran masih ditemukannya guru yang mengajar tidak seusai

\footnotetext{
${ }^{13}$ Suhasimi Arikunto, Penelitian Tindakan Kelas (Jakarta: Bumi Akasara, 2007). 58.

${ }^{14}$ Hasil wawancara bersama Guru SKI di MTsN Denanyar pada tanggal 20 Desember 2019

${ }^{15}$ Pedoman Khusus Pengembangan Silabus Berbasis Kompetensi SMP Mata Pelajaran PAI,
} 
dengan standar proses yang telah ditentukan. Penggunaan metode pembelajaran masih pada metode konvensional.

Sementara dalam hal media pembelajaran kemampuan guru untuk menciptakan media yang inovatif dan kreatifpun sangat minim. penulis melakukan observasi di suatu sekolah mengenai proses pembelajaran yang dilakukan guru dikelas. Dari hasil observasi tersebut guru yang mengajar khususnya pada Mata Pelajaran SKI sangat kurang dalam penggunaan metode pembelajaran yang kreatif dan inovatif. Proses pembelajaran didominasi dengan penggunaan metode ceramah, sehingga suasana kelas begitu tidak teratur, tidak tenang, bahkan banyak siswa yang mengantuk ketika mendengarkan pembelajaran, karena kurangnya kemampuan guru dalam menguasai metode pembelajaran ketika proses pembelajaran berlangsung. Hal tersebut menyebabkan terjadinya permasalahan berupa rendahnya motivasi siswa dalam belajar akibat dari suasana pembelajaran yang tidak efektif dan efisien sehingg tujuan pembelajaran yang sebelumnya telah dirangcang oleh guru tidak tercapai sebagaimana yang diharapakan.

Berdasarkan hal tersebut, adapun solusi yang ditawarkan oleh penulis dalam rangka mewujudkan pembelajaran PAIKEM (Pembelajaran Aktif, Inovatif, Kreatif, Efektif, dan Menyenangkan) maka yang dapat dilakukan yaitu melalui penerapan melalui metode bermain peran (role playing). ${ }^{16}$

Tabel 1 .

Kompetensi Dasar dan Indikator

\begin{tabular}{|l|l|}
\hline Kompetensi Dasar & Indikator \\
\hline l.1 Menceritakan Silsilah dan Kepribadian Abu & l.l.1 Mampu menjelaskan silsilah dan \\
Bakar As Sidiq serta perjuangannya dalam & kepribadian Khalifah Abu Bakar As Sidiq \\
dakwah Islam & $\begin{array}{l}\text { l.l.2 mampu menjelaskan perjuangan Khalifah } \\
\text { Abu Bakar As Sidiq }\end{array}$ \\
\hline
\end{tabular}

Sebelum membuat konsep penerapan metode role playing (bermain peran) berbasis desain pembelajaran, guru menyiapkan materi yang akan diperagakan oleh peserta didik. Pengembangan media pembelajaran Pendidikan Agama Islam dengan metode role playing (bermain peran) ini menggunakan kurikulum 2013. Pada silabus tercantum kompetensi inti dan kompetensi dasar beserta materi sejarah kebudayaan islam tentan perkembangan kebudayaan dan peradaban islam pada masa dinasti umayyah. Berdasarkan pada analisis kurikulum diatas, maka kompetensi dasar pada materi perkembangan kebudayaan/peradaban islam pada masa dinasti umayyah terbagi pada sub bab materi sebagai berikut:

Adapun konsep penerapan Metode role playing (bermain peran) Berbasis Desain Pembelajaran adalah sebagai berikut:

1. Guru dan peserta didik bekerjasama menyusun dan menyiapakn skenario yang akan ditampilkan yakni materi masuknya islam di nusantara. Skenario yang dirancang oleh guru dan peserta didik hendaknya berisi rangkaian dan apa saja yang harus ditampilkan oleh peserta didik. Sehingga peserta didik dapat mengembakan sendiri jalan cerita dan solusi mengenai kasus yang diangkat.

2. Guru menunjuk beberapa siswa untuk mempelajari skenario sebelum dilakukannya pementasan (seminggu sebelum atau dua hari sebelum KBM) ketika guru memperkenalkan materi pembelajaran yang akan dipelajari oleh siswa, maka guru dituntut untuk memberitahukan kepada siswa kegiatan pembelajaran apa saja yang akan

\footnotetext{
${ }^{16}$ R. Mardiyan, "Peningkatan Keaktifan Dan Hasil Belajar Siswa Dalam Pembelajaran Akuntansi Materi Jurnal Penyesuaian Pada Siswa Kelas XI IPS 3 SMA Negeri Bukit Tinggi Dengan Metode Bermain peran (role playing) (Role Playing)," Pakar Pendidikan (n.d.): 151-162.
} 
dilakukan termasuk adanya skenario yang diberikan oleh guru seminggu atau dua hari sebelum KBM dilaksanakan. Pemberian skenario tersebut ditentukan langsung oleh guru berdasarkan kesepakatan dengan siswa sebagai stakeholder.

3. Guru membentuk kelompok siswa yang anggotanya 5 orang, Pembagian kelompok dalam hal ini disesuaikan pula dengan jumlah siswa dalam kelas. Yakni murid yang memerankan masuknya islam di nusantara melalui perdagangan, perkawinan, dakwah, pendidikan dan Guru harus mampu mengefiesiensikan waktu dengan jumlah peserta pada masing-masing kelompok.

4. Guru memberikan kejelasan tentang kompetensi yang ingin dicapai. Adanya penjelasan terkait kompetesi yang harus dicapai oleh siswa agar siswa tersebut juga dapat mengetahui tujuan pembelajaran.

Dampak dari penggunaan Desain Pembelajaran modul pada mata pelajaran Sejarah Kebudayaan Islam pada materi masuknya Islam di nusantara sangat signifikan dengan hasil belajar para peserta didik. Desain Pembelajaran modul dengan metode bermain peran ini membuat peserta didik tidak merasa bosan ketika belajar Sejarah Kebudayaan Islam, bahkan mereka sangat antusias dalam memerankan setiap peran yang didapatkan.

Beberapa faktor pendukung dalam implementasi desain pembelajaran role playing (bermain peran) pada mata pelajaran Sejarah Kebudayaan Islam dalam meningkatkan hasil belajar siswa MTS Badrussalam a. pendidik harus menyadari tentang desain pembelajaran yang terbaru dalam belajar mengajar.b. guru harus memiliki kemampuan yang dapat menigkatkan keberhasilan belajar peserta didik. c. pendidik mampu mengembangakan desain pembelajaran, mengatur peserta didikn dan mengadakan evaluasi. d. peserta didik menerima dan dapat menerapkan desain pembelajaran role playing (bermain peran). Sedangakan faktor penghambat desain pembelajaran bermain peran adalah: a. pendidik mengalami kesulitan menghadapi karakteristik peserta didik. b. pendidik masih merasa kesulitan dalam menentukan materi dan metode pembelajaran yang sesuai dengan karakteristik peserta didik. c. Beberapa siswa masih terlihat malu-malu saat pembelajaran menggunakan menggunakan metode Role Playing.

Metode role playing memberikan dorongan motivasi tersendiri bagi siswa di MTs Badrussalam, hal ini memenuhi beberapa aspek, (1) kepraktisan produk yang digunakan tidak mempersulit kegiatan belajar siswa dan guru, mudah didapatkan; (2) hasil pengamatan peneliti yang mengambil dari sempel kelas VII, menunjukan minat menvisualkan pelajaran dengan mengambar sangat tinggi dan menunjukan siswa lebih aktif di kelas; (3) model pendekatan seperti ini juga sangat efektif dengan kurangnya penunjang teknologi berbasis ICT bagi siswa. 


\section{Kesimpulan}

Metode role playing (bermain peran) dalam penelitian ini merupakan tindakan terpola secara sistematis untuk mencapai tujuan pembelajaran dalam bentuk penggunaan pengalihan dari sebuah teori yang sulit dipahami menjadi sebuah pertunjukan. Metode role playing (bermain peran) sangat cocok untuk meningkatkan keaktifan siswa sejak dini, kegiatan ini akan membiasakan siswa menjadi kritis terhadap apa yang dipelajarinya. Dengan minimnya media pembelajaran yang digunakan di MTs Badrussalam pendekatan metode role playing (bermain peran) mampu memberikan alternatif pembelajaran yang lebih efektif, sehingga hal ini dapat merangsang motivasi belajar siswa. 


\section{Daftar Pustaka}

Arikunto, Suhasimi. Penelitian Tindakan Kelas. Jakarta: Bumi Akasara, 2007.

Bermawy M, Hisyam Zaini, and Sekar A.A,. Strategi Pembelajaran Aktif. Yogyakarta: Pustaka Insan Madani, 2008.

Depdiknas. Pedoman Khusus Pengembangan Silabus Berbasis Kompetensi SMP Mata Pelajaran PAI,. Jakarta: Direktorat Jendral Pendidikan Lanjutan Pertama, 2003.

Jalinus, Nizwardi, and Ambiyar. Media Dan Sumber Pembelajaran. Jakarta: Kencana, 2016.

Mardiyan, R. "Peningkatan Keaktifan Dan Hasil Belajar Siswa Dalam Pembelajaran Akuntansi Materi Jurnal Penyesuaian Pada Siswa Kelas XI IPS 3 SMA Negeri Bukit Tinggi Dengan Metode Bermain Peran (Role Playing)." Pakar Pendidikan (n.d.): 151-162.

Moleong, L.J. Metode Penelitian Kualitatif. Bandung: Remaja Rosda Karya, 2007.

Rosdiana. "Penggunaan Media Pembelajaran Berbasis ICT Dan Pengaruhnya Terhadap Tingkat Kelulusan Ujian Nasional Siswa Pada Sekolah Menengah Di Kota Palopo (Studi Kasus Di 5 Sekolah Menengah Di Kota Palopo)." Al-Khawarizmi; Jurnal Pendidikan Matematika dan Ilmu Pengetahuan Alam 4. 1 (March 2016).

Sumiharsono, M. Rudy, and Hisbiyatul Hasanah. Media Pembelajaran. Jember: Pustaka Abadi, 2018.

Sunhaji. "Konsep Manajemen Kelas Dan Implikasinya Dalam Pembelajaran." Jurnal Kependidikan 2. 2 (November 2014).

Suryani, Nunuk. "Pengembangan Media Pembelajaran Berbasis IT." Prosiding Workhsop Nasional (November 2015).

Usman, Uzer. Menjadi Guru Profesional. Bandung: Remaja Rosdakarya, 2002.

Zainiyati, Husniyatus Salamah. Pengembangan Media Pembelajaran Berbasis ICT. Jakarta: Kencana, 2017. 


\section{First Author:}

1. Name: Nurul Kumalasari

2. Afiliation: Universitas Islam Negeri Sunan Ampel Surabaya, Indonesia

3. E-mail: nurulkumala03@gmail.com

4. Google Scholar: Nurul Kumalasari (https://scholar.google.co.id/citations?user=tXdVAmEAAAAJ\&ehl=id)

5. SINTA:

6. Orcid ID: Nurul Kumalasari (https://orcid.org/0000-0001-5911-9055) 